\title{
Urban manta rays: potential manta ray nursery habitat along a highly developed Florida coastline
}

\author{
Jessica H. Pate*, Andrea D. Marshall \\ Marine Megafauna Foundation, Truckee, CA, 96161, USA
}

\begin{abstract}
The giant oceanic manta ray Mobula birostris was listed in the US Endangered Species Act as a threatened species in 2018, yet insufficient data exist on manta populations throughout US waters to designate critical habitat. Taxonomic and genetic evidence suggests that manta rays in the Western Atlantic are a separate species ( $M$. cf. birostris) and little is understood about the ecology and life history of this putative species. The juvenile life stage of both $M$. birostris and $M$. cf. birostris is particularly understudied. Here, we are the first to describe the characteristics of a manta ray population along a highly developed coastline in southeastern Florida using boatbased surveys and photo identification of individuals. Fifty-nine manta individuals were identified between 2016 and 2019. All males were sexually immature based on clasper development, and $96 \%$ of females were classified as immature based on size and absence of mating scars or visible pregnancies. Twenty-five ( $42 \%)$ individuals were observed more than once during the study period and 8 individuals were sighted over multiple years. The occurrence of juveniles, high site fidelity and extended use of the study area by juvenile manta rays suggest that southeastern Florida may serve as a nursery habitat. High occurrence of fishing line entanglement $(27 \%$ of individuals) and vessel strike injury were documented, and rapid wound healing was observed. Future research and conservation efforts will focus on identifying the physical and biological features of the potential nursery habitat and on mitigation of anthropogenic impacts.
\end{abstract}

KEY WORDS: Manta ray $\cdot$ Nursery habitat $\cdot$ Anthropogenic impacts $\cdot$ Vessel strike $\cdot$ Entanglement

\section{INTRODUCTION}

Globally, manta rays (Mobula birostris and M. alfredii) are classified as Vulnerable on the IUCN Red List, mainly due to targeted fishing and bycatch (Marshall et al. 2018). Manta and mobula rays have been targeted globally for their gill plates, which are transported and sold in Asia as health tonics (Dulvy et al. 2014, Croll et al. 2016). The conservative life-history traits of manta rays (i.e. late age of maturity, long gestation period, low fecundity) make them particularly susceptible to exploitation (Dulvy et al. 2014) and rising anthropogenic threats. Other significant, yet less-studied threats to manta rays include ingestion of microplastics (Germanov et al. 2019b), vessel-strike injuries (McGregor et al. 2019), unsustainable tourism

\footnotetext{
${ }^{*}$ Corresponding author: jessica.pate@marinemegafauna.org
}

(Venables et al. 2016), habitat destruction and climate change (Stewart et al. 2018a).

Recent taxonomic (Marshall et al. 2009) and genetic (Hinojosa-Alvarez et al. 2016, J. Hosegood et al. unpubl. at https://doi.org/10.1101/458141) evidence indicates there is a third species of manta ray (M. cf. birostris), which is noted to occur off the Atlantic coast of the USA. M. cf. birostris, though most closely related to $M$. birostris (Hinojosa-Alvarez et al. 2016, J. Hosegood et al. unpubl. at https://doi. org/10.1101/458141), is thought to be more similar in ecology to $M$. alfredi; however, there is a lack of data on populations from the Caribbean and Western Atlantic. As for many batoids, large gaps exist in the knowledge of manta ray life history and ecology (Martins et al. 2018). M. alfredi associates with neritic habitats and is the better studied of the 2 manta

(1) The authors 2020. Open Access under Creative Commons by Attribution Licence. Use, distribution and reproduction are unrestricted. Authors and original publication must be credited. 
species, with data on gestation period (1 $\mathrm{yr}_{\text {; }}$ Marshall \& Bennett 2010b, Stevens 2016), age at maturity (8-17 yr for females; Marshall et al. 2019) and size at birth (130-190 cm; Stevens 2016, Murakumo et al. 2020). Less is known about the life history of $M$. birostris, as a result of its tendency to reside in more remote open-ocean habitats (Marshall et al. 2018).

The life stage of sexually immature or juvenile manta rays remains particularly understudied. Of the 663 currently described batoid species, less than $6 \%$ have been the subject of studies concerning nursery habitats (Martins et al. 2018). Heupel et al. (2007) defined testable criteria of an elasmobranch nursery habitat as: (1) more juveniles are found in the proposed nursery area than in other areas, (2) individuals have a tendency to remain over time, and (3) the habitat is repeatedly used across years. While juvenile manta ray habitats are slowly being identified around the world, only 2 have been described that meet these criteria (M. birostris and M. cf. birostris: Childs 2001, Stewart et al. 2018b; M. alfredi: Germanov et al. 2019a). Juvenile survival rates are particularly important to population viability in species where there is a late age of maturity, high adult survival and low fecundity (Heppell et al. 2000). As global manta ray populations decline, the importance of survival at the juvenile life stage makes identifying critical habitats, including pupping and nursery areas, a priority for manta ray research and conservation efforts (Stewart el al. 2018a).

Southeast Florida is characterized by a narrow (2$10 \mathrm{~km}$ ) continental shelf and warm waters from the north-flowing Florida Current (Banks et al. 2007, Finkl \& Andrews 2008). Nearshore waters of southeast Florida support many populations of marine megafauna including sea turtles (Makowski et al. 2005, Stewart et al. 2014), bottlenose dolphins (Tursiops truncatus; Litz et al. 2007), spotted eagle rays (Aetobatus narinari; Newby et al. 2014), goliath grouper (Epinephelus itajara; Koenig et al. 2017) and sharks (Kajiura \& Tellman 2016). These megafauna have been subjected to increased harassment, injury and mortality as the human population of south Florida continues to grow (Bureau of Economic and Business Research 2019) and the coastal waters are more heavily used for recreational activities such as boating, fishing, jet-skiing, snorkeling, SCUBA diving and swimming (Adimey et al. 2014, Powell et al. 2018, Foley et al. 2019).

The giant oceanic manta ray ( $M$. birostris) was listed on the US Endangered Species Act as a threatened species (NOAA 2018), yet insufficient data exist on the manta population along the eastern USA to designate critical habitat. At the time of writing, there have been no published studies of manta rays in Florida, with the exception of one paper documenting the sighting of 3 manta rays in the Indian River Lagoon in the 1990s (Adams 1998). However, fishermen have long been aware of seasonal manta ray aggregations in northern Florida and use the manta rays to target cobia Rachycentron canadum, a popular game fish (Fig. 1 shows a photo array of anthropogenic impacts to Florida manta rays including fishermen targeting cobia with manta rays). SCUBA diving is a popular pastime in Florida; yet, manta rays are rarely seen by divers on the reefs (REEF 2019; J. Pate pers. obs.).

Here, we provide the first description of manta rays along the southeast coast of Florida, USA. Using inwater observations, we documented the sex, size, maturity status, associated fish taxa, behavior and spatio-temporal distribution of this manta population. We further present evidence that our survey area meets the criteria of a batoid nursery habitat (Heupel et al. 2007, Martins et al. 2018). We also quantify negative anthropogenic interactions of manta rays with boating and fishing, as well as photographically document the rapid healing of injuries. Finally, we discuss the value and limitations of these data in regards to management, and suggest future avenues for research and conservation.

\section{MATERIALS AND METHODS}

\subsection{Boat-based surveys}

Visual boat-based surveys were conducted from June 2016 to November 2019 to locate and identify individual manta rays. A boat survey consisted of driving the boat at slow speeds $(<10$ knots) along a portion of a north-south transect between Jupiter Inlet (26 56 $\left.46^{\prime \prime} \mathrm{N}, 80^{\circ} 04^{\prime} 13^{\prime \prime} \mathrm{W}\right)$ and Boynton Beach Inlet (263' $34^{\prime \prime} \mathrm{N}, 80^{\circ} 02^{\prime} 31^{\prime \prime} \mathrm{W}$; Fig. 2), approximately $200 \mathrm{~m}$ from shore (distance from shore varied with conditions such as sea state and tide). This area was selected based on previous observations of manta rays swimming close to shore $(<3 \mathrm{~m}$ depth). Surveys were typically conducted between inlets (e.g. between Jupiter Inlet and Palm Beach Inlet; Fig. 2), though could be shorter or longer depending on conditions. For example, if weather conditions were favorable and no mantas were sighted between Jupiter and Palm Beach Inlet, we sometimes continued south to Boynton Beach Inlet or partway there. In 2019, some surveys extended farther north to St. Lucie Inlet $\left(27^{\circ} 09^{\prime} 48^{\prime \prime} \mathrm{N}, 80^{\circ} 09^{\prime} 11^{\prime \prime} \mathrm{W}\right.$; Fig. 2) when manta rays were difficult to locate in our standard survey area. 

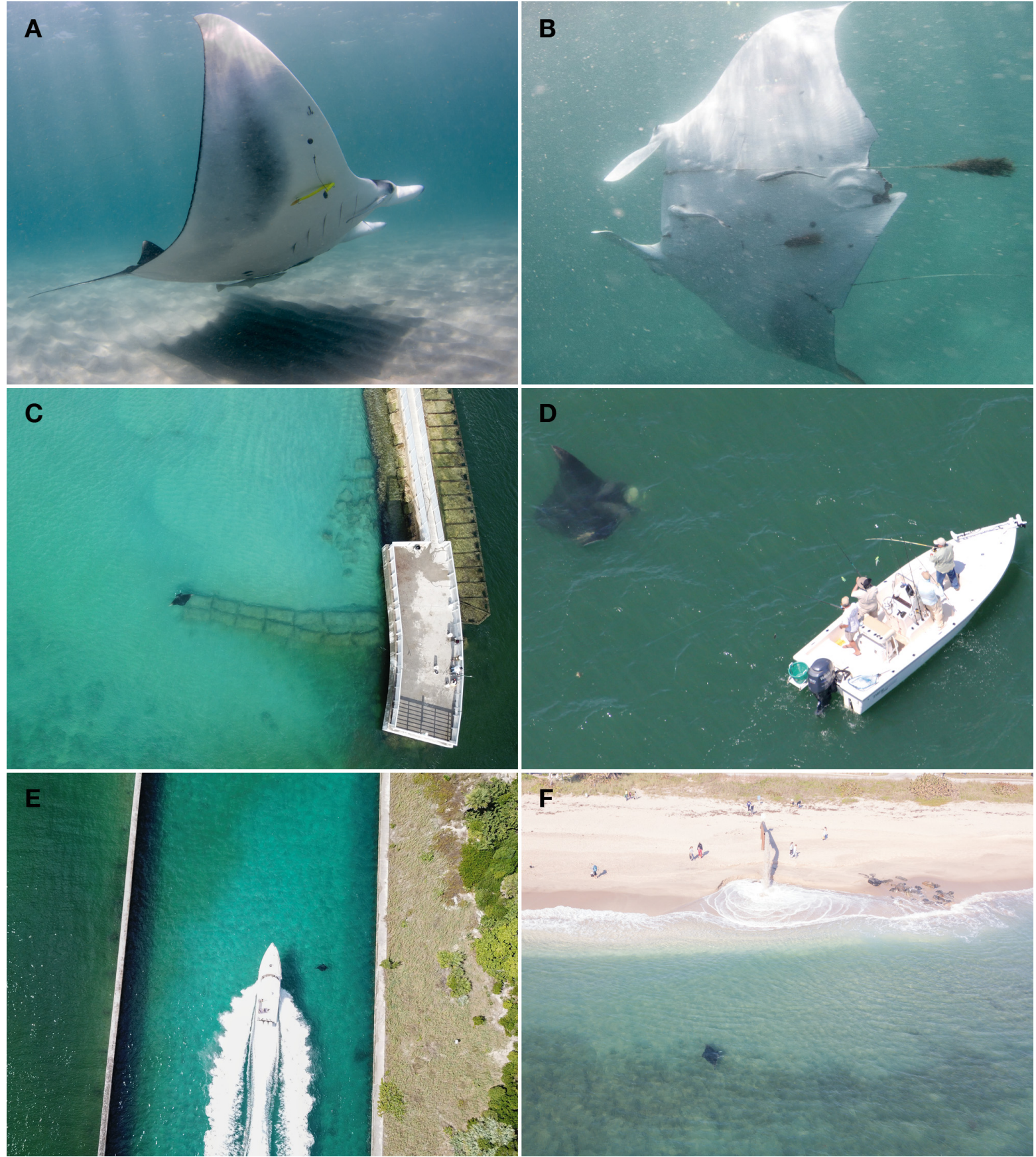

Fig. 1. Anthropogenic interactions with manta rays. Fishing line interactions on (A) a female manta ray with hooks in the pectoral fin and (B) a manta ray with multiple fishing line entanglements, including one that is cutting into the right pectoral fin, as well as evidence of a shark bite. Manta rays in south Florida are found in areas of high human activity: (C) a manta ray by a popular fishing jetty, (D) fishermen in northern Florida targeting cobia that swim with manta rays, (E) a manta ray inside Boynton Beach Inlet with a boat passing, and $(\mathrm{F})$ a manta swimming in shallow coastal water along a public beach by a dredging outflow pipe

Surveys normally began in the mornings $(\sim 09: 00 \mathrm{~h})$ when winds were typically lighter. An observer stood on the bow of the boat (Triumph $215 \mathrm{CC}$ ) for the best vantage point. Unmanned aerial vehicles (UAVs; DJI Mavic Pro \& DJI Phantom 4; commonly drones) or planes were used on $26 \%(\mathrm{n}=46)$ of surveys in 2018 and 2019. We were unable to fly UAVs in a portion of our study area due to flight restrictions around airports. An encounter was defined as any time a manta ray was located by an observer or UAV. When a 


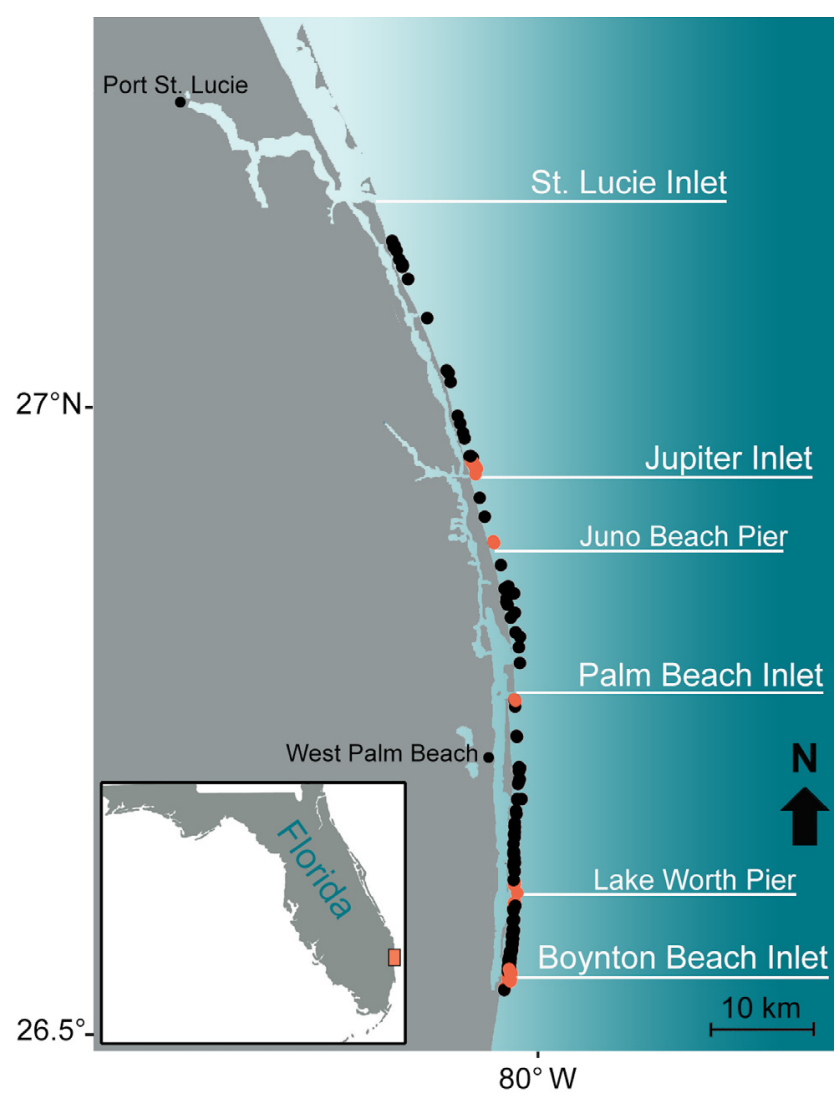

Fig. 2. Map of the survey area along the Atlantic coast of Florida. Each circle represents a manta ray encounter. Orange circles indicate a manta ray that was encountered within $1 \mathrm{~km}$ of a fishing pier or inlet jetty

manta ray was located, GPS location, water depth, water temperature and bottom cover type (sand or hard bottom) were recorded. Water temperature was not recorded during 2016 surveys.
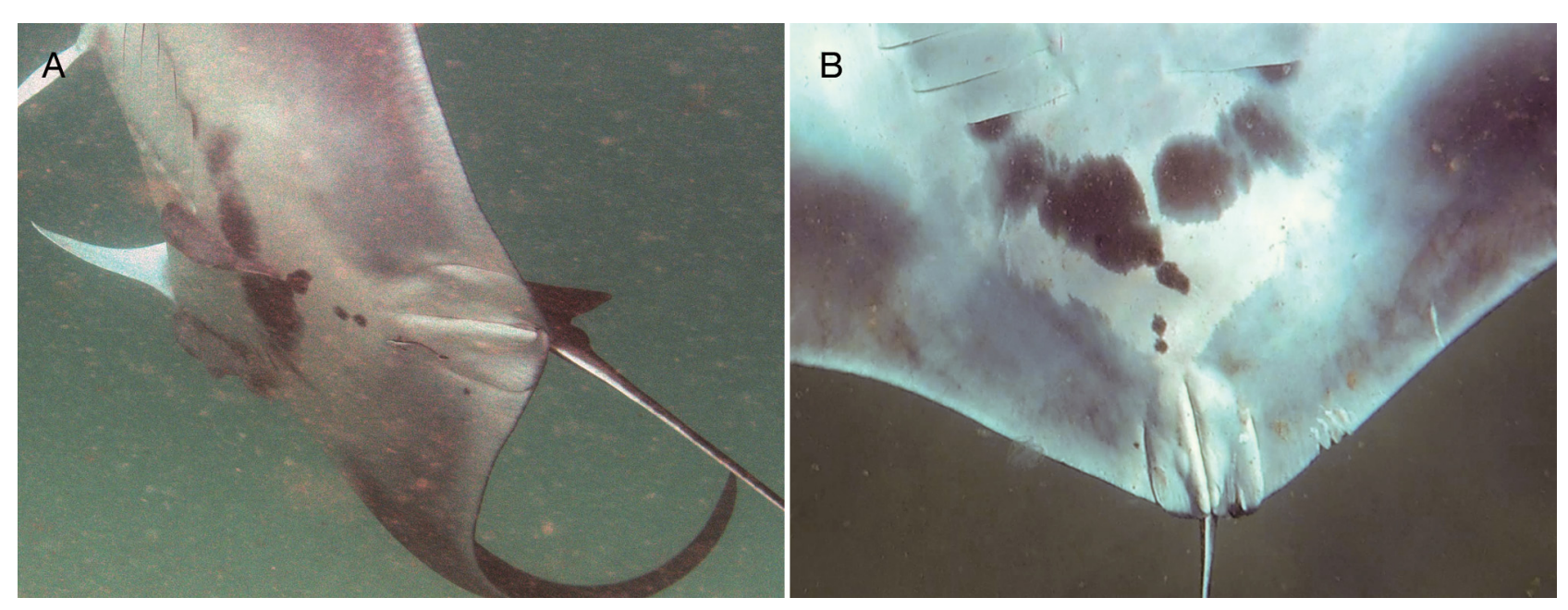

Fig. 3. Small, uncalcified claspers that do not exceed beyond pelvic fins. Claspers of manta ray FL0027 on (A) 25 August 2017 and (B) 24 June 2019

When a manta ray was located, a snorkeler entered the water to obtain a visual identification photograph of the ventral spot pattern. It was not possible to obtain a usable identification photo for all manta rays, and some manta rays were lost before a snorkeler was able to enter the water. Since the manta rays were frequently in shallow water $(<2 \mathrm{~m})$ swimming close to the seafloor, the snorkeler would often use an extended GoPro to reach underneath the manta ray while continuously recording. Still frames were extracted from GoPro videos for analysis. Distinguishing features such as scars, injuries and color patterns were also noted. Photo-identification is a commonly accepted method of identifying manta ray individuals and the methodology has been extensively documented (Marshall et al. 2011, Kitchen-Wheeler et al. 2012, Couturier et al. 2014). Disc width was estimated by the in-water snorkeler by comparing manta to an object of known size (i.e. snorkeler or the research vessel) to the nearest foot $(0.3 \mathrm{~m})$. Due to the inaccuracies of this method and estimator bias, we further binned individuals into $1 \mathrm{~m}$ size classes to allow for at least a broad-scale overview of the general sizes of encountered individuals.

\subsection{Population structure}

A photo of the pelvic fins was taken to determine sex (by presence or absence of claspers), and a chisquare test (RStudio 1.2.5042) tested for a significant departure from a 1:1 sex ratio. Maturity status was determined for males by relative size of claspers. Juvenile male claspers are small and uncalcified, and do not extend past the pelvic fins (Fig. 3). Sex- 
ually mature males have calcified claspers that extend well past pelvic fins and fully developed clasper glands (see Fig. 3 in Marshall \& Bennett 2010b). Female maturity was assessed by disc width and the presence of mating scars (Marshall \& Bennett 2010b) or visible pregnancy. Mating scars are found on the distal end of the pectoral fin, usually the left (Marshall \& Bennett 2010b). Though these scars may decrease in intensity, they persist over time and are easily recognized by trained observers. Females of Mobula birostris mature at disc widths $>4 \mathrm{~m}$ (Marshall et al. 2018), and females of $M$. alfredi mature at $3.0-3.5 \mathrm{~m}$ disc width (Marshall et al. 2019). We conservatively assumed that females with a disc width less than $3 \mathrm{~m}$ and an absence of mating scars were immature. If the female was greater than $3 \mathrm{~m}$, but lacked scars or visible pregnancy, the maturity status of females was considered unknown. Each identified manta ray individual was classified as $M$. birostris or $M$. cf. birostris based on the key provided in Marshall et al. (2009) (Fig. 4). To ensure that no individuals belonged to $M$. alfredi, photos were analyzed for presence of a caudal spine. Lack of a caudal spine is a diagnostic feature of $M$. alfredi.

Manta ray behavior was also recorded as 'directed swimming', 'feeding', 'cleaning' or 'reproductive' (Germanov et al. 2019a). Directed swimming manta rays maintained a directional heading and did not frequently change directions, as often observed in feeding manta rays. Manta rays directionally swimming would sometimes unroll one or both cephalic fins in response to the snorkeler. Manta rays were considered to be feeding if the cephalic lobes were unrolled and the mouth and gill slits were open. Cleaning behavior is characterized by a manta ray hovering, usually over a reef, while being cleaned by juvenile reef fish. Reproductive behavior included any observation of courtship or mating (Stevens et al. 2018). If the behavior did not fall clearly into the categories described above, it was labeled as 'not determined'.

A re-sighting was defined as a sighting of a manta ray individual on a different survey day. Time and straight-line distance were calculated between each re-sighting of an individual. Average time and distance were calculated between all manta ray resightings. Re-sightings were also collected from citizen science divers/snorkelers, sometimes outside the survey area. Sightings outside the survey area were excluded from the time and distance re-sighting analysis.

\subsection{Associated species}

In Florida, manta rays are used by fishermen to locate and target cobia Rachycentron canadum, though this association is better known in northern Florida. In our survey area, some fishermen have reported that the number of cobias associating with manta rays has decreased over time (J. Pate pers. obs.). Here, we used our photos and videos to quantify fish taxa associated with each manta ray encountered in our study area. Fish were considered associated with the manta ray if they were swimming close to the manta ray $(<1 \mathrm{~m})$ in the same direction for the duration of the encounter or if they were physically attached to the manta ray. Videos were only used if a complete view of the dorsal and ventral side was available. Fish were identified to genera if possible, but for many we were only able to identify to family.

\subsection{Anthropogenic impacts}

Injuries and fishing line entanglement were noted and/or photographed in each encounter. Fishing line and injury location on the manta ray was documented as anterior ventral (AV), posterior ventral $(\mathrm{PV})$, pectoral ventral $(\mathrm{PeV})$, anterior dorsal $(\mathrm{AD})$, posterior dorsal (PD), pectoral dorsal (PeD) (Fig. 5). If injuries were in more than one body region, both were selected. If not possible to see where the hook was attached, it was categorized as no hook/line entanglement $(\mathrm{NH})$. When possible, attached fishing gear was removed from manta rays.

Wherever possible, injuries and scars were photographed and the cause was identified. Propeller injuries were identified by multiple parallel linear wounds (Byard et al. 2013, Foley et al. 2019), sometimes with a perpendicular linear wound caused by the skeg (Fig. 6). Shark bites were identified by crescent shaped scarring or teeth rake marks (Marshall \& Bennett 2010a) (Fig. 1B). Fishing line was listed as the cause of injury if it was still attached to the manta ray and was visibly causing injury, or if there was a remnant scar/injury from the line (similar to the one on the right pectoral fin of the manta ray in Fig. 1B). Other injuries (nicks, slices or missing tissue) were categorized as unknown cause, though the origin of the wound is likely anthropogenic (McGregor et al. 2019). Injuries were considered to have recently occurred if any fresh, vascularized flesh was exposed (Fig. 6A-D,F,I) and considered healed otherwise. If the injured individual was re-sighted, photos were taken to assess the rate of wound healing. Wounds 


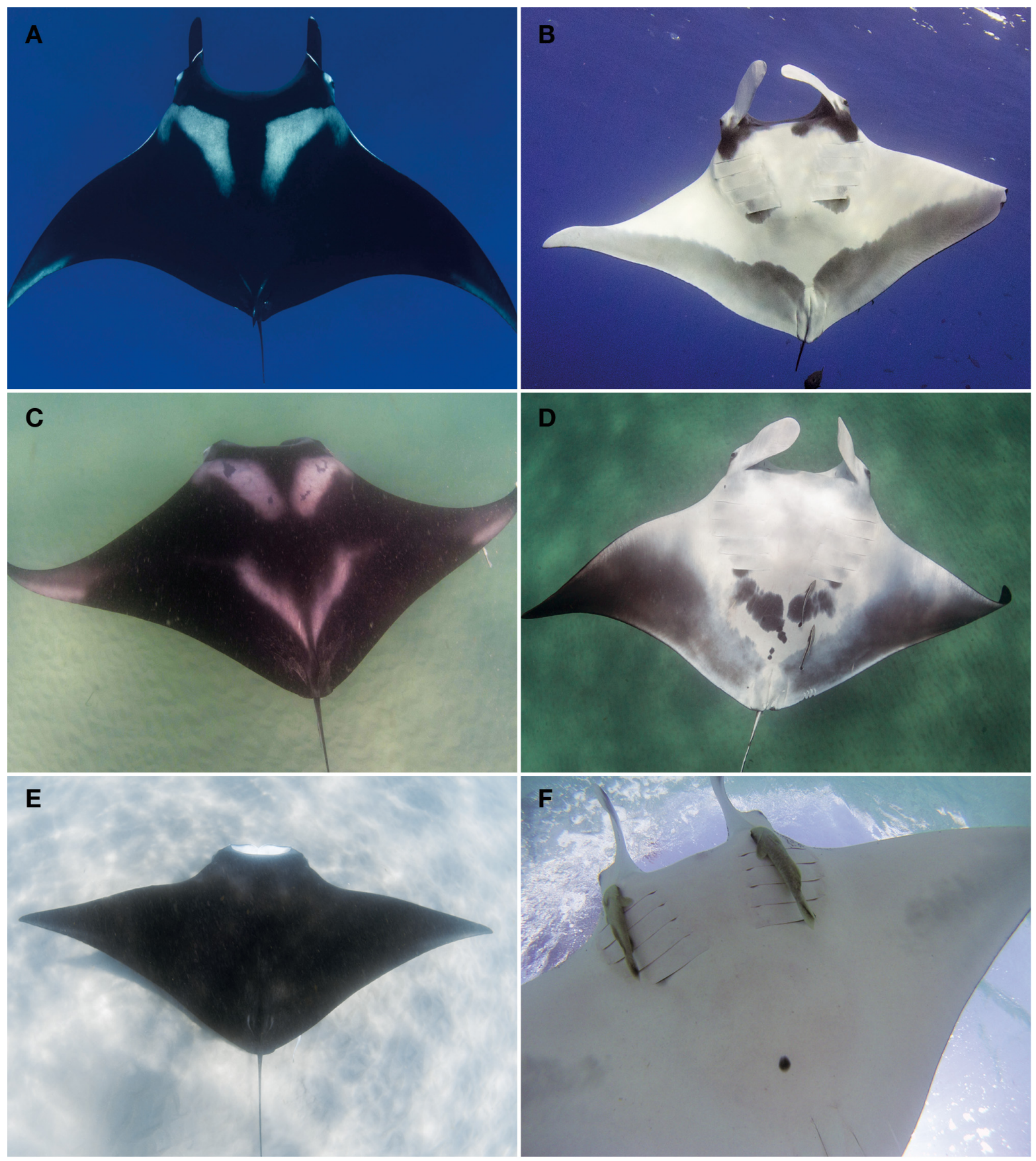

Fig. 4. Photos showing (A) dorsal and (B) ventral coloration of Mobula birostris and variation in $(\mathrm{C}, \mathrm{E})$ dorsal and $(\mathrm{D}, \mathrm{F})$ ventral coloration of M. cf. birostris. Mobula birostris photos were taken in Revillagigedo Archipelago, Mexico. Mobula cf. birostris photos are from the present study

were considered healed when completely closed (Fig. 6E,H,J).

To quantify manta ray proximity to areas of high human impact, straight-line distance was calculated with Google Earth between every manta ray location and the nearest fishing pier or inlet jetty. Manta ray mortalities were opportunistically documented.

\section{RESULTS}

\subsection{Boat-based surveys}

A total of 175 boat-based surveys were conducted between June 2016 and December 2019. The number of surveys and seasonal effort varied each year 


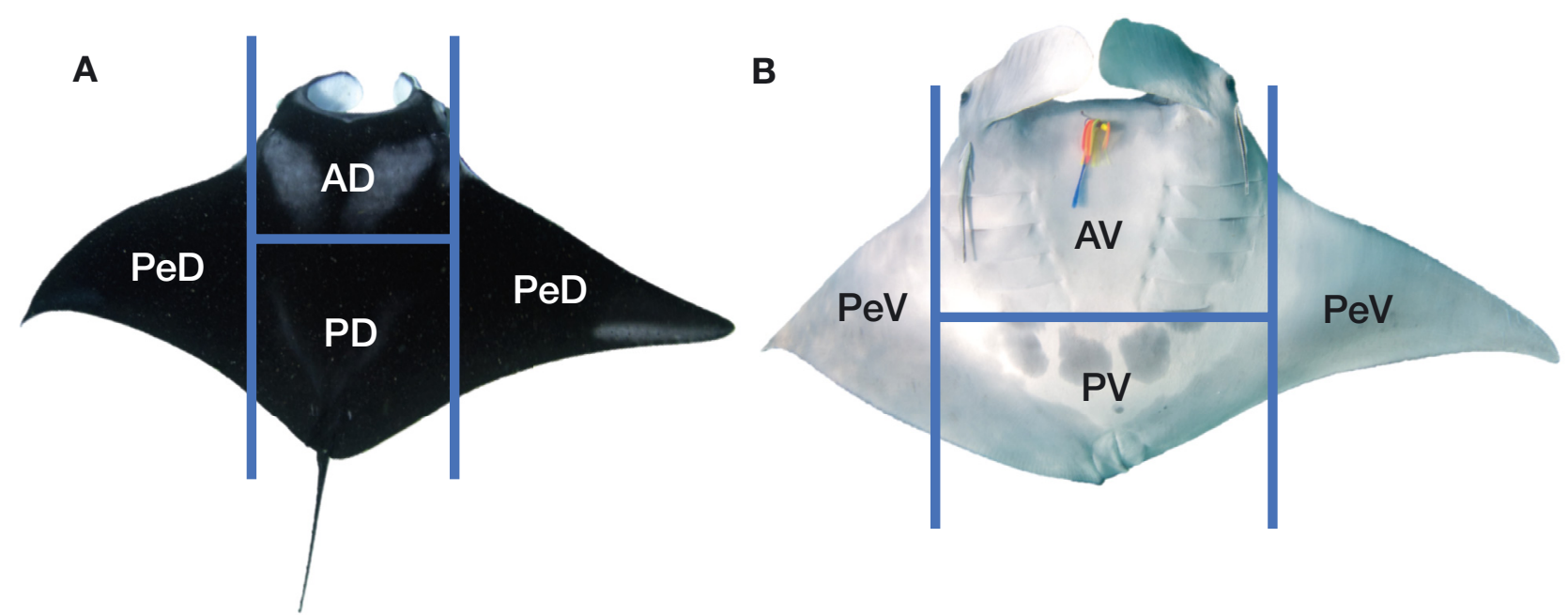

Fig. 5. Diagram of fishing line locations, (A) dorsal and (B) ventral. Dorsal pectoral (PeD) is the area lateral to the line made posteriorly from the lateral edge of white shoulder patch. Anterior dorsal (AD) is the area anterior of white shoulder patches and medial of pectoral fins, with posterior dorsal (PD) being the area posterior to this. Ventral pectoral (PeV) is the area lateral to the distal end of the 1st gill slit. Anterior ventral (AV) is the area anterior to the 5th gill slit and medial to the pectoral fins

(includes the cephalic fins), and posterior ventral (PV) is posterior to this. A fishing lure can be seen in the AV region

(Fig. 7; 2016: 15 surveys; 2017: 46 surveys; 2018: 56 surveys; 2019: 58 surveys), with $66 \%$ of surveys conducted during the summer months (June-August). Manta rays were observed on $42.9 \%$ of surveys $(\mathrm{n}=$ 75). A maximum of 8 manta rays were encountered in a single survey.

One hundred and fifty manta ray encounters occurred during the study period (Fig. 8; 2016: 11 encounters; 2017: 66 encounters; 2018: 28 encounters; 2019: 45 encounters). Photographic identification was obtained for 130 (87\%) of these encounters. Manta rays were found in an average $( \pm \mathrm{SE})$ water depth of $2.7 \mathrm{~m}( \pm 0.1 \mathrm{~m}$, range $0.8-9.8 \mathrm{~m})$ and water temperature of $28.0^{\circ} \mathrm{C}\left( \pm 0.1^{\circ} \mathrm{C}\right.$, range $\left.23.2-30.1^{\circ} \mathrm{C}\right)$. One hundred and twenty-seven $(84.7 \%)$ manta ray encounters occurred over a sandy seafloor, 17 $(11.3 \%)$ over hard bottom and for $6(4 \%)$ encounters, habitat was not recorded.

\subsection{Manta ray individuals and population structure}

Of the 150 encounters, 59 unique manta ray individuals were identified (Fig. 8). The sampled individuals consisted of 31 male $(52.5 \%)$ and 28 female $(47.5 \%)$ manta rays, a sex ratio (1.1:1) that did not differ significantly from parity (chi-square test, $\chi^{2}{ }_{1}=$ $0.15254, \mathrm{p}=0.6961)$. All male manta rays $(\mathrm{n}=31)$ were sexually immature based on clasper size. Ninety-six percent $(n=27)$ of females were sexually immature based on disc width $(<3 \mathrm{~m})$ and absence of mating scars. Seventeen $(29 \%)$ of the photographi- cally identified manta ray individuals' disc widths at first sighting were $<2 \mathrm{~m}, 41$ were between 2 and $3 \mathrm{~m}$ $(69 \%)$ and 1 individual was over $3 \mathrm{~m} \mathrm{(2 \% ;} \mathrm{Fig.} \mathrm{9).}$ The single individual estimated to be greater than $3 \mathrm{~m}$ disc width was female, but lacked mating scars or visible pregnancy, thus maturity status was considered unknown (Fig. 9).

All identified individuals were classified as Mobula cf. birostris based on the key in Marshall et al. (2009). An examination of a subset of individuals $(n=5)$ in the field by A. D. M. further confirmed that all examined individuals possessed skin morphology similar to that of $M$. cf. birostris (Marshall et al. 2009). Eighty-three percent of manta rays had photos where the base of the tail was clearly visible, and in all of them a caudal spine was present. Eighty-six $(58 \%)$ of the manta ray encounters were behaviorally categorized as directed swimming, $37(25 \%)$ were categorized as feeding and for $26(17 \%)$ manta ray encounters behavior was not determined. No cleaning or reproductive behavior was observed.

Twenty-five manta rays ( $42 \%$ ) were sighted more than once, with a total of 78 re-sighting events. Of these re-sighted manta ray individuals, $48 \%$ were seen twice, $24 \% 3$ times, $8 \% 4$ times and $16 \%$ between 5 and 9 times (average $4.1 \pm 0.9$ sightings; range $2-23$; median $=3$ ). Four of these re-sightings were reported by boaters or divers, 3 outside our survey area. One individual was on a wreck east of our survey area, and 2 others were sighted $60 \mathrm{~km}$ south of the survey area. An average of $70.9 \mathrm{~d}$ lapsed between each re-sighting ( $\pm 11.9 \mathrm{~d}$; range $1-387 \mathrm{~d})$ and 

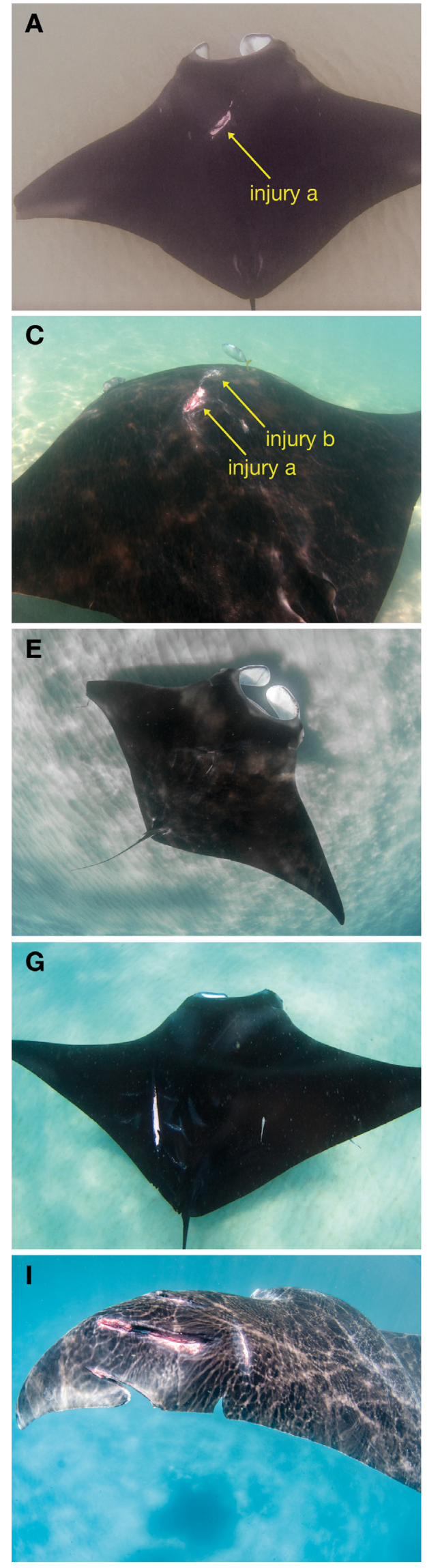
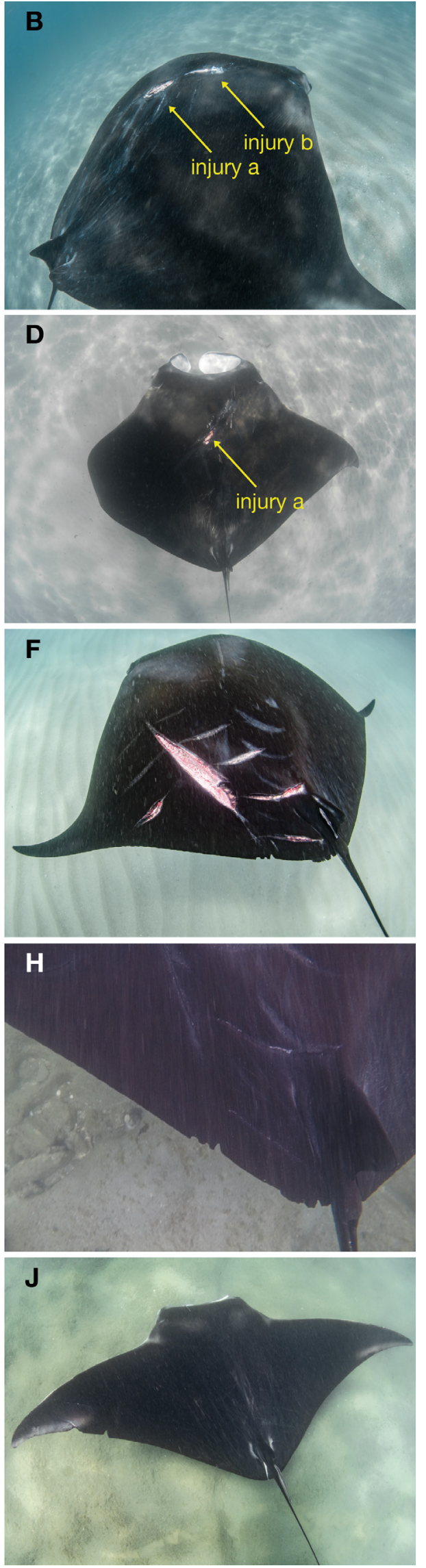

Fig. 6. Photos of propeller injuries to juvenile male manta ray FL009 on (A) 7 July 2017, (B) 18 July 2017, (C) 24 July 2017, (D) 2 August 2017 when injury b is healed and (E) 16 August 2017 when injury a is healed. Propeller injury to a juvenile male manta ray, FL0027, on (F) 15 August 2018, (G) 19 August 2018 and $(\mathrm{H})$ completely healed on 9 September 2018. A female manta ray, FL0020, on (I) 2 July 2018 and $(\mathrm{J})$ with healed injury on 15 August 2018 


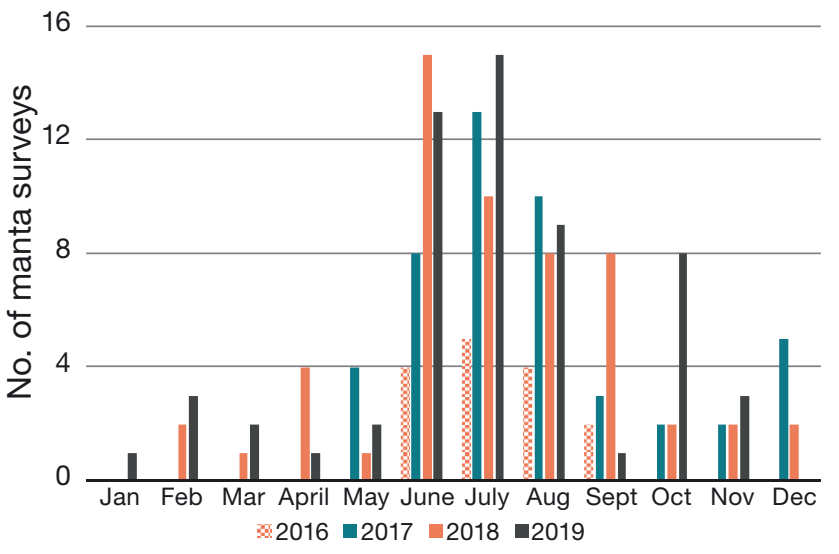

Fig. 7. Seasonal survey effort over the 2016-2019 study period ( $\mathrm{n}=175$ surveys)

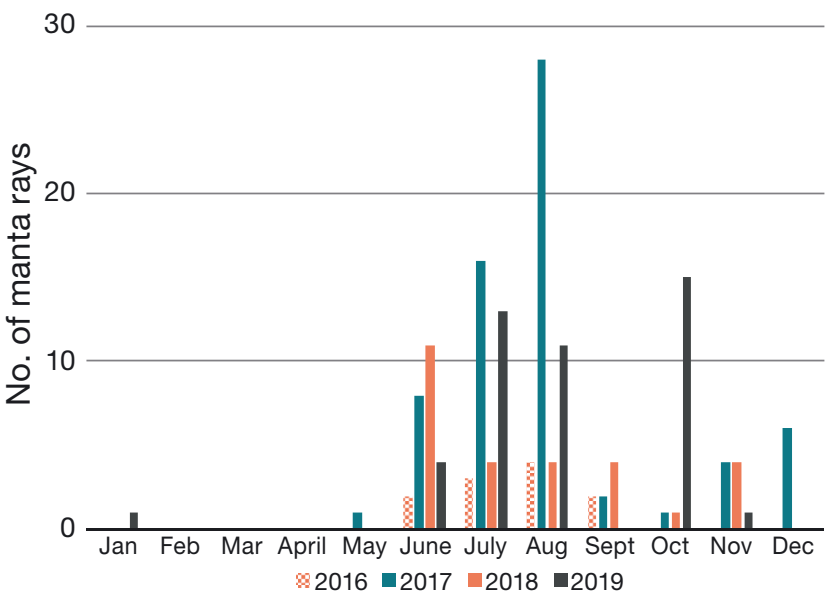

Fig. 8. Total manta ray sightings per month from 2016 to $2019(n=150$ encounters $)$

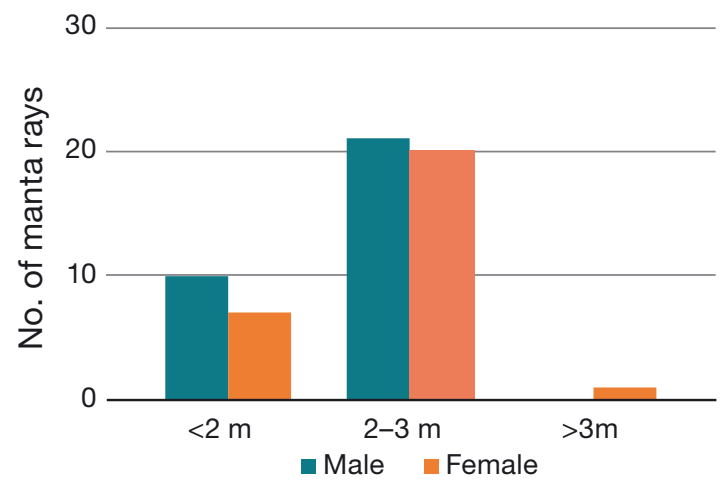

Fig. 9. Disc widths of the 59 identified manta ray individuals by sex

manta rays were observed an average distance of $15.1 \mathrm{~km}( \pm 2.0 \mathrm{~km}$; range $0.03-65.6 \mathrm{~km})$ away from their previously sighted location. Time between the initial sighting of an individual manta ray and the final sighting averaged $208 \mathrm{~d}( \pm 50 \mathrm{~d}$; range 1-825 d, 24 individuals).
Individual manta rays used the survey area across years, with 8 individuals being sighted in at least 2 consecutive calendar years. Two of these mantas (FL0020, female, and FL0027, juvenile male) were sighted in 3 consecutive years $(2017,2018,2019)$. FL0027 was observed 23 times between 16 August 2017 and 22 October 2019. Over the entire period, its clasper size indicated a juvenile age class, with claspers not extending past the pelvic fins (Fig. 3).

\subsection{Associated species}

Ninety-seven $(65 \%)$ videos of manta encounters provided a full dorsal and ventral view for associated species analysis (comprising 46 individuals). Fish of the family Echeneidae represented $82 \%(n=229)$ of fish found with manta rays. Other fish found were jacks (Family Carangidae, genera Caranx spp. and Carangoides spp., $\mathrm{n}=47,17 \%$ ), scad (Decapterus spp., $\mathrm{n}=3,1 \%$ ) and cobia Rachycentron canadum $(\mathrm{n}=2,0.7 \%)$. The median number of fish per manta ray (data right-skewed) was $2( \pm 0.3$; range $0-27)$. In 6 encounters, no fish were observed in association with the manta ray.

\subsection{Anthropogenic impacts}

Of encounters with photographically identified manta rays, $99 \%$ had a ventral photo and $87 \%$ had a dorsal photo. Since we were not able to examine both sides for all manta rays, entanglement and injury frequency represent a minimum for our study group. Sixteen individuals $(27 \%)$ were seen foul-hooked or entangled in fishing line, of which 6 individuals interacted with fishing gear more than once. The most common area hooked was the ventral pectoral fin $(\mathrm{PeV}, 37 \%$; Table 1). Fifty-two percent of manta rays were hooked in the pectoral fin (dorsal and ventral; Table 1). Seventeen percent of hooked manta rays were hooked in the anterior ventral ( $\mathrm{AV}$; Table 1), near the mouth and gills (Figs. 1B \& 7B).

Thirty-three injuries were documented on 27 $(46 \%)$ manta individuals. Ten $(30 \%)$ of the injuries were presumably from boat propellers, 10 (30\%) from fishing line, 9 (27\%) from an unknown cause and $4(12 \%)$ from shark bites. Seven injuries were considered to have recently occurred, with 5 of those being caused by boat propellers. All propeller injuries occurred on the dorsum (with one cutting through to the ventral side as well, Fig. 6I), with $55 \%$ on the posterior, $27 \%$ on the anterior and $18 \%$ on the 
Table 1. Physical location of fishing hooks on manta ray bodies (Fig. 5). In 30 manta encounters, a fishing gear interaction was documented. In 8 encounters, no hook was seen and the fishing line was wrapped around the manta

\begin{tabular}{|lcccc|}
\hline & Anterior & Posterior & Pectoral & Total \\
\hline Dorsal & 1 & 0 & 5 & 6 \\
Ventral & 5 & 0 & 11 & 16 \\
Total & 6 & 0 & 16 & \\
\hline
\end{tabular}

Table 2. Physical location of injuries on manta ray bodies (Fig. 5). Twelve injuries were classified in more than one body region

\begin{tabular}{|lcccc|}
\hline & Anterior & Posterior & Pectoral & Total \\
\hline Dorsal & 3 & 13 & 13 & 29 \\
Ventral & 1 & 4 & 11 & 16 \\
Total & 4 & 17 & 24 & \\
\hline
\end{tabular}

pectoral dorsum (Table 2). Eighty percent of fishing line injuries occurred on the pectoral fin (Table 2). We documented healing times on 4 injuries (on 3 individuals). These wounds completely healed in 40 and $15 \mathrm{~d}$ (FL009, injury a and injury b, respectively), $44 \mathrm{~d}$ (FL0020) and $25 \mathrm{~d}$ (FL0027; Fig. 6).

Forty-two manta rays $(28 \%)$ were encountered within $1 \mathrm{~km}$ of a fishing pier or inlet jetty (Figs. 1 \& 2). Only one manta ray mortality occurred during the study period, but this occurred outside the study area. Florida Fish and Wildlife Commission was notified of a dead manta ray entangled in a vessel exclusion line (steel cable) on 18 July 2017 in Pompano Beach, Florida $\left(26^{\circ} 13^{\prime} 16.4^{\prime \prime} \mathrm{N}\right.$, $80^{\circ} 5^{\prime} 17.3^{\prime \prime} \mathrm{W}$, south of our survey area). The female measured $2.48 \mathrm{~m}$ in disc width and had no other signs of injury or fishing line entanglement. It is likely that the manta ray became entangled in the line and drowned. This manta ray had not been previously photographically identified in our surveys.

\section{DISCUSSION}

Documenting nursery habitats is a priority in manta ray research and conservation (Stewart et al. 2018a), yet only 2 nurseries (Mobula birostris in Texas, USA: Stewart et al. 2018b; M. alfredi in Indonesia: Germanov et al. 2019a) have been identified that meet the criteria of an elasmobranch nursery habitat (Heupel et al. 2007). We provide evidence that our survey area meets these criteria: (1) more juveniles are found in the proposed nursery area than in other areas, (2) individuals have a tendency to remain over time, and (3) the habitat is repeatedly used across years.

All males observed were sexually immature and $96 \%$ of females were of immature size without mating scars (criterion 1). Other populations in the western Atlantic, namely in the Yucatan Peninsula, Mexico (Marshall \& Holmberg 2018), and northeastern Florida (Mullican et al. 2013, A. Marshall pers. obs.), consist mostly of adult manta rays. Juvenile $M$. birostris are rarely encountered in surveys of most manta populations, making this population somewhat unique, albeit similar to the one described in the Flower Garden Banks (Stewart et al. 2018b). Additionally, manta ray individuals in the south Florida population remained over time (criterion 2), with $42 \%$ of individuals being sighted more than once within the study period. One juvenile male manta ray (FL0027) was sighted 23 times over $797 \mathrm{~d}$. Finally, we demonstrate that the nearshore waters of south Florida are used repeatedly among years (criterion 3). Manta rays were seen in every year of the study and aerial surveys for shark migrations have documented manta rays every year from 2011 to 2019 (J. Waldron \& S. M. Kajiura unpubl. data). Individual manta rays were also shown to utilize the study area over consecutive calendar years.

While our survey area fits the criteria for a nursery habitat, it is still unclear how large this critical habitat may be. Manta rays are capable of long-distance migrations and deep dives (Jaine et al. 2014), thus our survey area likely does not encompass the entirety of the nursery habitat. Our methodology is limited by logistics and skewed towards finding manta rays in shallow, clear water. Thus, while we are confident that our study site represents a portion of the nursery habitat, we are unsure of the geographical limits of habitat use by juvenile manta rays in Florida. Two of our photographically identified manta rays were seen by a local free-diver in shallow water $60 \mathrm{~km}$ south of our survey area, evidence that the nursery habitat may extend farther north, south and possibly east of our survey area.

Nursery habitats tend to provide conditions beneficial for development, such as food availability and protection from predators (Heupel et al. 2007). Feeding behavior was observed in the proposed nursery habitat, sometimes involving groups of up to 5 individuals. These feeding events are likely manta rays taking advantage of ephemeral bursts of productivity, possibly from upwelling caused by eddies of the nearby Florida Current (Lirman et al. 2019) or nutri- 
ent-rich discharge from coastal inlets (Sonnetag \& McPherson 1984). The large size of manta rays at birth protects them from many potential predators, except for large sharks. Only 4 (6.8\%) of photographically identified manta rays were observed with shark bites, suggesting that predation rates are low within the study area. Similar rates of predation have been reported for juvenile $M$. alfredi (Deakos et al. 2011), suggesting juvenile manta rays may be selecting habitat, at least in part, based on predation risk. It is important to note that predation rates may be underestimated if mortality is cryptic in juvenile manta rays, and that our approach only documented manta rays that survived predation attempts.

Manta ray proximity to areas of high human use (i.e. inlets and fishing piers) likely contributes to frequency of fishing line entanglement and vessel strike (Fig. 2). In French Polynesia, manta rays near inhabited islands are more likely to be observed with sublethal injuries caused by fishing gear or boat strikes than mantas near uninhabited islands (Carpentier et al. 2019). The human population of Florida increased $262 \%$ from 1960 to 2008 , with $75 \%$ of people living in coastal counties (Wilson \& Fishetti 2010). In eastern Florida, participation in recreational fishing increased 58\% between 1981 and 2016 (pers. comm. from the National Marine Fisheries Service, Fisheries Statistics Division, 24 January 2020). Of the 3 manta rays documented by Adams (1998) in a Florida estuary 25 yr ago, 1 individual had deep lacerations from a propeller and was entangled in fishing gear. This suggests that anthropogenic interactions have been occurring for decades and are likely increasing as the human population of Florida increases.

The largest threat to global manta ray populations is targeted fisheries and bycatch (Croll et al. 2016), yet less is known about sub-lethal interactions between manta rays and recreational fishing gear (Stewart et al. 2018a). Twenty-seven percent of manta ray individuals in the present study were foulhooked or entangled in fishing line (Fig. 1), with $38 \%$ of those individuals having more than one interaction with fishing gear, an extremely high rate of anthropogenic interaction for small manta rays to sustain in their first years of life. Many marine megafauna, including dolphins, manatees and sea turtles, in Florida have been documented as entangled in fishing gear and these interactions are increasing (Adimey et al. 2014).

Most (52\%) of the fishing hooks were on the pectoral fin of manta rays (Table 1). Similarly, Adimey et al. (2014) found that sea turtles and manatees were most often entangled on their flippers. These lateral hooking locations are indicative of passive interactions with fishing gear, i.e. interactions when a freeswimming animal accidentally comes into contact with the fishing gear. Active interaction with fishing gear results from an animal seeking food or exploring a novel object (Adimey et al. 2014). Deakos et al. (2011) documented evidence of fishing hooks on manta ray cephalic fins in a Hawaiian population, with a $10 \%$ cephalic lobe injury rate, likely caused by entanglement in monofilament line. Variation in fishing behavior and gear may result in variation in severity and location of foul-hooking and/or entanglement. This would require that the appropriate mitigation strategies be tailored for each manta ray population and fishery. In Florida, fishermen target manta rays based on their well-known association with cobia, yet we rarely saw cobia with manta rays in our survey area.

While some fishing interactions may result in minimal permanent injury to the manta ray, they likely cause considerable stress and possible sub-lethal effects. When fishermen have accidentally hooked manta rays, fight times have been over one hour ( $\mathrm{J}$. Pate unpubl. data). Fight time is correlated with physiological stress (i.e. lactate production) in elasmobranchs, with smaller sharks producing more lactate than larger sharks (Gallagher et al. 2014). Thus small, juvenile manta rays may be especially vulnerable to stress from capture. Additionally, fishing line wrapped around the mouth or cephalic fin can also affect a manta's ability to feed. Studies on other marine taxa also demonstrate reduced time spent foraging after anthropogenic interaction (Williams et al. 2006). Furthermore, stress from capture can induce early parturition in many elasmobranch species, including M. birostris (Adams et al. 2018).

We documented $46 \%$ of individuals with scars or injuries. Although it can be difficult to determine the origin of many of the scars and injuries to manta rays, we were able to document 10 incidents where an outboard motor was the clear cause of a recent injury (denoted by multiple parallel linear injuries from propellers; usually there was another deeper, linear injury perpendicular to propeller marks from the sharp edge of the skeg; Fig. 6).

McGregor et al. (2019) documented rapid healing of a vessel strike in a single $M$. alfredi female. They found that $95 \%$ of the wound closed within $295 \mathrm{~d}$ (though this is likely an overestimate of healing time since they had to wait for the next season for the manta ray to be re-sighted) and modeled a healing half-life of $46 \mathrm{~d}$. We were not able to obtain as highquality photos for measuring wounds as McGregor et 
al. (2019). However, we were still able to document wound healing, from time of first injury observation to complete wound closure, for 4 injuries on 3 mantas ( 2 males, 1 female; Fig. 6). Complete wound closure ranged from 15 to $44 \mathrm{~d}$, much faster than previously documented in manta rays (Marshall \& Bennett 2010a, McGregor et al. 2019; Fig. 6), yet similar to healing rates in wild blacktip reef sharks Carcharhinus melanopterus (Chin et al. 2015).

Rapid wound healing certainly leads to an underestimation of frequency of vessel strike injuries (McGregor et al. 2019). Once healed, these wounds appear as barely visible light gray scars (Fig. 6) and may not be noticed in a quick underwater encounter. It is also possible that manta rays are experiencing blunt force trauma from a vessel strikes, yet are not exhibiting any obvious external injuries. Nine percent of stranded sea turtles in Florida from 1984 to 2014 were found to have blunt force injuries probably caused by vessel strikes (Foley et al. 2019). Manta ray strandings in Florida are rare (D. Adams pers. comm.), yet mortality may be cryptic as manta rays are negatively buoyant and will sink when they die.

\section{CONCLUSIONS}

The nearshore area between St. Lucie Inlet and Boynton Beach Inlet in southeast Florida has been identified as a potential nursery habitat for manta rays. Ninety-eight percent of manta rays observed were juveniles, and many individuals showed high site fidelity to the study area, which occurs along a highly populated coastline with intensive human traffic. We also documented wounds and entanglement consistent with high rates of negative interactions with fishermen and boaters, which are likely underestimated due to rapid wound healing in manta rays.

In 2018, M. birostris was listed as threatened under the US Endangered Species Act, which requires that critical habitat of listed species be designated. However, to designate critical habitat, NOAA requires that the physical and biological features essential to conservation of the species be identified. As of 2019, NOAA determined that no such critical habitat had yet been identified (NOAA 2019). We suggest that this coastline be considered in future designations as a potential nursery habitat for this species. Very few juvenile manta ray habitats have been identified (Stewart et al. 2018b, Germanov et al. 2019a), making it crucial to identify and protect known or suspected nursery grounds.
We recommend the use of aerial surveys, acoustic and satellite telemetry, as well as studies of prey availability to further elucidate the physical and biological features of this potential nursery habitat. Future research in this area should also focus on ontogenetic habitat shifts, as these juvenile rays presumably reach the age to join the greater adult population, and the connectivity of this population with others regionally. The manta rays in our study appear to represent a third species of $M$. cf. birostris (Marshall et al. 2009, J. Hosegood et al. 2019 unpubl. at https://doi.org/10.1101/458141) and the conservation status of this species is unknown, warranting further research into the life history and genetics of this population.

Acknowledgements. This research was made possible by generous funding from the Kansas City Zoo, Brevard Zoo Quarters for Conservation Grant, Our Children's Earth Foundation and the Zoos and Aquariums Committing to Conservation Grant. Many wonderful volunteers made this fieldwork possible: M. Gilroy, T. Touchton, D. Kirwan, E. Broadus, G. Broadus, C. Pate, G. Pate, J. Baney, D. Turffs, K. Berriz, O. Cortes, K. McQueeney, J. Peterson, C. Peterson, D. Azevedo, S. McGuire, K. Robertson and B. Ruddy. Beautiful photographs were contributed by B. Augliere, N. Ientile and B. Turffs. B. Victor helped with identification of associated fish taxa. The map of survey area was made by S. Venables. Comments by P. Allman and S. Hoffman improved the text of this manuscript. We thank 4 anonymous reviewers, who greatly improved the quality of this paper.

\section{LITERATURE CITED}

Adams DH (1998) Occurrence of the manta ray, Manta birostris, in the Indian River Lagoon, Florida. Fla Sci 61: 7-9

Adams KR, Fetterplace LC, Davis AR, Taylor MD, Knott NA (2018) Sharks, rays and abortion: the prevalence of capture-induced parturition in elasmobranchs. Biol Conserv 217:11-27

Adimey NM, Hudak CA, Powell JR, Bassos-Hull K and others (2014) Fishery gear interactions from stranded bottlenose dolphins, Florida manatees and sea turtles in Florida, USA. Mar Pollut Bull 81:103-115

* Banks KW, Riegl BM, Shinn EA, Piller WE, Dodge RE (2007) Geomorphology of the Southeast Florida continental reef tract (Miami-Dade, Broward, and Palm Beach Counties, USA). Coral Reefs 26:617-633

Bureau of Economic and Business Research (2019) Florida estimates of population 2019. University of Florida, Gainesville. https://www.bebr.ufl.edu/sites/default/files/ Research\%20Reports/estimates_2019.pdf

* Byard RW, Machado A, Woolford L, Boardman W (2013) Symmetry: the key to diagnosing propeller strike injuries in sea mammals. Forensic Sci Med Pathol 9:103-105

Carpentier AS, Berthe C, Ender I, Jaine FRA and others (2019) Preliminary insights into the population characteristics and distribution of reef (Mobula alfredi) and oceanic ( $M$. birostris) manta rays in French Polynesia. Coral Reefs 38:1197-1210 
Childs JN (2001) The occurrence, habitat use, and behavior of sharks and rays associating with topographic highs in the Northwestern Gulf of Mexico. Texas A\&M University. https://oaktrust.library.tamu.edu/handle/1969.1/ETDTAMU-2001-THESIS-C45 (accessed 29 Dec 2019)

Chin A, Mourier J, Rummer JL (2015) Blacktip reef sharks (Carcharhinus melanopterus) show high capacity for wound healing and recovery following injury. Conserv Physiol 3:cov062

Couturier LIE, Dudgeon CL, Pollock KH, Jaine FR and others (2014) Population dynamics of the reef manta ray Manta alfredi in eastern Australia. Coral Reefs 33:329-342

Croll DA, Dewar H, Dulvy NK, Fernando D and others (2016) Vulnerabilities and fisheries impacts: the uncertain future of manta and devil rays. Aquat Conserv 26: 562-575

* Deakos MH, Baker JD, Bejder L (2011) Characteristics of a manta ray Manta alfredi population off Maui, Hawaii, and implications for management. Mar Ecol Prog Ser 429:245-260

* Dulvy NK, Pardo SA, Simpfendorfer CA, Carlson JK (2014) Diagnosing the dangerous demography of manta rays using life history theory. PeerJ 2:e400

Finkl CW, Andrews JL (2008) Shelf geomorphology along the Southeast Florida Atlantic Continental Platform: barrier coral reefs, nearshore bedrock, and morphosedimentary features. J Coast Res 244:823-849

Foley AM, Stacy BA, Hardy RF, Shea CP, Minch KE, Schroeder BA (2019) Characterizing watercraft-related mortality of sea turtles in Florida. J Wildl Manag 83: 1057-1072

* Gallagher AJ, Serafy JE, Cooke SJ, Hammerschlag N (2014) Physiological stress response, reflex impairment, and survival of five sympatric shark species following experimental capture and release. Mar Ecol Prog Ser 496:207-218

* Germanov ES, Bejder L, Chabanne DBH, Dharmadi D and others (2019a) Contrasting habitat use and population dynamics of reef manta rays within the Nusa Penida Marine Protected Area, Indonesia. Front Mar Sci 6:215

Germanov ES, Marshall AD, Hendrawan IG, Admiraal R and others (2019b) Microplastics on the menu: plastics pollute Indonesian manta ray and whale shark feeding grounds. Front Mar Sci 6:679

Heppell SS, Hal C, Crowder LB (2000) Life histories and elasticity patterns: perturbation analysis for species with minimal demographic data. Ecology 81:645-665

Heupel MR, Carlson JK, Simpfendorfer CA (2007) Shark nursery areas: concepts, definition, characterization and assumptions. Mar Ecol Prog Ser 337:287-297

*Hinojosa-Alvarez S, Walter RP, Diaz-James P, Galvan-Magana F, Paig-Tran EM (2016) A potential third manta ray species near the Yucatán Peninsula? Evidence for a recently diverged and novel genetic manta group from the Gulf of Mexico. PeerJ 4:e2586

* Jaine FRA, Rohner CA, Weeks SJ, Couturier LIE, Bennett MB, Townsend KA, Richardson AJ (2014) Movements and habitat use of reef manta rays off eastern Australia: offshore excursions, deep diving and eddy affinity revealed by satellite telemetry. Mar Ecol Prog Ser 510: 73-86

Kajiura SM, Tellman SL (2016) Quantification of massive seasonal aggregations of blacktip sharks (Carcharhinus limbatus) in Southeast Florida. PLOS ONE 11:e0150911

Kitchen-Wheeler AM, Ari C, Edwards AJ (2012) Population estimates of Alfred mantas (Manta alfredi) in central
Maldives atolls: North Male, Ari and Baa. Environ Biol Fishes 93:557-575

*Koenig CC, Bueno LS, Coleman FC, Cusick JA and others (2017) Diel, lunar and seasonal spawning patterns of the Atlantic goliath grouper, Epinephelus itajara, in Florida, United States. Bull Mar Sci 93:391-406

Lirman D, Ault JS, Fourqurean JW, Lorenz JJ (2019) The coastal marine ecosystem of south Florida, United States. In: Sheppard C (ed) World Seas: an environmental evaluation, Vol I: Europe, The Americas, and West Africa, 2nd edn. Elsevier, London, p 427-444

* Litz JA, Garrison LP, Fieber LA, Martinez A, Contillo JP, Kucklick JR (2007) Fine-scale spatial variation of persistent organic pollutants in bottlenose dolphins (Tursiops truncatus) in Biscayne Bay, Florida. Environ Sci Technol 41:7222-7228

Makowski C, Seminoff JA, Salmon M (2005) Home range and habitat use of juvenile Atlantic green turtles (Chelonia mydas L.) on shallow reef habitats in Palm Beach, Florida. Mar Biol 148:1167-1179

Marshall AD, Bennett MB (2010a) The frequency and effect of shark-inflicted bite injuries to the reef manta ray Manta alfredi. Afr J Mar Sci 32:573-580

Marshall AD, Bennett MB (2010b) Reproductive ecology of the reef manta ray Manta alfredi in southern Mozambique. J Fish Biol 77:169-190

*Marshall AD, Holmberg J (2018) MantaMatcher Photo-identification Library. www.mantamatcher.org/ (accessed 22 May 2020)

* Marshall AD, Compagno LJV, Bennett MB (2009) Redescription of the genus Manta with resurrection of Manta alfredi (Krefft, 1868) (Chondrichthyes; Myliobatoidei; Mobulidae). Zootaxa 2301:1-28

* Marshall AD, Dudgeon CL, Bennet MB (2011) Size and structure of a photographically identified population of manta rays Manta alfredi in southern Mozambique. Mar Biol 158:1111-1124

*Marshall AD, Bennett MB, Kodja G, Hinojosa-Alvarez S and others (2018) Mobula birostris (amended version of 2011 assessment). The IUCN Red List of Threatened Species 2018: e.T198921A126669349. http://dx.doi.org/ 10.2305/IUCN.UK.2018-1.RLTS.T198921A126669349.en (accessed 25 Jan 2020)

*Marshall A, Barreto R, Carlson J, Fernando D and others (2019) Mobula alfredi. The IUCN Red List of Threatened Species 2019: e.T195459A68632178. https://dx.doi.org/ 10.2305/IUCN.UK.2019-3.RLTS.T195459A68632178.en. (accessed 20 March 2020)

Martins APB, Heupel MR, Chin A, Simpfendorfer CA (2018) Batoid nurseries: definition, use and importance. Mar Ecol Prog Ser 595:253-267

*McGregor F, Richardson AJ, Armstrong AJ, Armstrong AO, Dudgeon CL (2019) Rapid wound healing in a reef manta ray masks the extent of vessel strike. PLOS ONE 14: e0225681

Mullican T, Hampp J, Tyminski J (2013) Aerial survey and satellite tagging of manta rays in coastal waters of Northeast Florida. In: International Conference on Oceanography \& Natural Disasters, Aug 21-23, Orlando, FL. https://www.omicsonline.org/proceedings/aerial-survey-satellite-tagging-of-manta-rays-in-coastal-waters-ofnortheast-florida-9427.html

* Murakumo K, Matsumoto R, Tomita T, Yousuke M, Ueda K (2020) The power of ultrasound: observation of nearly the entire gestation and embryonic developmental pro- 
cess of captive reef manta rays (Mobula alfredi). Fish Bull 118:1-7

Newby JN, Darden T, Shedlock AM (2014) Population genetic structure of spotted eagle rays, Aetobatus narinari, off Sarasota, Florida and the Southeastern United States. Copeia 2014:503-512

NOAA (National Oceanic and Atmospheric Administration) (2018) Endangered and Threatened Wildlife and Plants; Final Rule To List the Giant Manta Ray as Threatened Under the Endangered Species Act. Fed Regist 83: 2916-2931

NOAA (2019) Endangered and Threatened Species; Determination on the Designation of Critical Habitat for Giant Manta Ray. Fed Regist 84:66652-66664

Powell JR, Machernis AF, Engleby LK, Farmer NA, Spradlin TR (2018) Sixteen years later: an updated evaluation of the impacts of chronic human interactions with bottlenose dolphins (Tursiops truncatus truncatus) at Panama City, Florida, USA. J Cetacean Res Manag 19:79-93

REEF (2019) Reef Environmental Education Foundation Volunteer Fish Survey Project Database. www.REEF.org (accessed 7 Feb 2020)

Sonnetag HW, McPherson FB (1984) Nutrient input from the Loxahatchee River environmental control district sewage-treatment plant to the Loxahatchee River estuary, southeastern Florida. Water-Resource Investigation Report 84-4020, US Geological Survey, Tallahassee, FL

Stevens GMW (2016) Conservation and population ecology

Editorial responsibility: Austin Gallagher,

Herndon, Virginia, USA of manta rays in the Maldives. PhD thesis, University of York

Stevens GMW, Hawkins JP, Roberts CM (2018) Courtship and mating behaviour of manta rays Mobula alfredi and M. birostris in the Maldives. J Fish Biol 93:344-359

* Stewart KR, Martin KJ, Johnson C, Desjardin N, Eckert SA, Crowder LB (2014) Increased nesting, good survival and variable site fidelity for leatherback turtles in Florida, USA. Biol Conserv 176:117-125

* Stewart JD, Jaine FRA, Armstrong AJ, Armstrong AO and others (2018a) Research priorities to support effective manta and devil ray conservation. Front Mar Sci 5:314

Stewart JD, Nuttall M, Hickerson EL, Johnston MA (2018b) Important juvenile manta ray habitat at Flower Garden Banks National Marine Sanctuary in the northwestern Gulf of Mexico. Mar Biol 165:111

* Venables S, McGregor F, Brain L, van Keulen M (2016) Manta ray tourism management, precautionary strategies for a growing industry: a case study from the Ningaloo Marine Park, Western Australia. Pac Conserv Biol 22:295-300

* Williams R, Lusseau D, Hammond PS (2006) Estimating relative energetic costs of human disturbance to killer whales (Orcinus orca). Biol Conserv 133:301-311

Wilson SG, Fishetti TR (2010) Coastline population trends in the United States: 1960-2008. Population estimates and projections. Current Population Reports. US Department of Commerce, Economics and Statistics Administration, US Census Bureau, Washington, DC, p 25-1139

Submitted: April 3, 2020; Accepted: July 3, 2020 Proofs received from author(s): August 26, 2020 